N OCTOBER 17, 1965, the Texas chapter of the Daughters of Founders and Patriots of America unveiled a historical marker at San Angelo, Texas, commemorating the establishment of the first Christian mission in Texas by Father Juan de Salas. The Franciscan missionary came from Santa $\mathrm{Fe}$, New Mexico, in 1629 to establish a mission among the Jumano Indians, probably in the area of present-day San Angelo.

M ANY institutions joined in the celebration of the hundredth anniversary of the death of Andrés Bello in October, 1965. Most outstanding in honoring this pioneer South American man of letters were the National Committees which were established for the occasion in Venezuela, where he was born on November 29, 1781, and in Chile, where he died on October 15,1865 . In Colombia a solemn celebration of the centenary was declared by presidential decree. The Association of Academies of Language, with its principal seat in Madrid, has established norms for awarding an Andrés Bello Prize. In Paris a statue of Bello was unveiled in the Square of Latin America. In the Netherlands, Ibero-American Day (October 19) was dedicated to the personality of Bello, and Prince Bernhard presided over the proceedings. Expressions of public homage in England were held at Canning House and the University of Cambridge. The Ibero-American Institutes of Berlin and Hamburg also organized observances in honor of Bello. During the fourth meeting of the Inter-American Cultural Council in Washington, D. C., in January, 1966, a bust of Andrés Bello was presented to the Pan American Union.

\title{
RECENT DEATHS
}

$\mathbf{R}^{\prime}$ ALPH L. ROYS, noted for his studies of Mayan anthropology, died in Seattle, Washington, on Sunday, December 12, 1965, at 86 years of age. He was a corresponding member of the Academy of American Franciscan History. For many years he was a member of the department of historical research of the Carnegie Institute of Washington. He was associated with the Mayan research program of Tulane University and was later Wade research professor of anthropology at the University of Washington. His published works include The Ethno-Botany of the Maya (New Orleans, 1931), The Book of Chilam Balam of Chumayel (Washington, 1933), and The Indian Background of Colonial Yucatan (Washington, 1943). His last publication, Ritual of the Bacabs (Norman, Oklahoma, 1965), is reviewed in this issue.

NILS HEDBERG, founder of the Instituto Ibero-Americano of Göteborg, Sweden, died on November 24, 1965, of a heart ailment. For twentyfive years he was the guiding spirit of the Institute, making every effort to foster a cultural interchange between Sweden and the Hispanic world. He not only saw considerable success in this effort but he also promoted the development of the library of the Institute, which is one of the better collections of Spanish and Portuguese books in northern Europe. 